is expected to be considerable, but the project is not being approached from a purely economic point of view. It is felt that its main purpose should be to fulfil an obligation to future generations and to honour responsibilities undertaken in the 1933 International Convention for the Protection of the Fauna and Flora of Africa.

\title{
WILD ELEPHANTS IN ASSAM
}

\author{
By E. P. GeE
}

Reprinted with permission from Loris, the Journal of the Ceylon Game and Fauna Protection Society

Even in this age of atomic energy and jet propulsion, the market for elephants is still strong. Their value as a means of extracting timber in thick forests, as a mode of transport in otherwise inaccessible tracts of country and for ceremonial uses has not in the least declined.

There are those who, misled by the elephants' huge size, overestimate their strength, and work them till they break down. Then they decry them as weak and delicate animals. Admittedly elephants are, size for size, about a quarter less strong than a horse and slightly weaker even than man. But with the necessary knowledge of their habits in their wild state, and with proper care and attention, these sagacious and docile creatures will perform a great variety of tasks and get through an enormous amount of heavy work, resulting in an appreciable saving of man-power and complicated mechanical devices.

The elephants' services to mankind have long been fully appreciated. And the necessity of maintaining the stock of wild animals at a reasonable and safe level, and of controlling the otherwise indiscriminate catching operations and shooting for ivory, led our forefathers to pass the Elephants' Preservation Act. Under this Government of India Act of 1879, it was decreed that no wild elephant shall be killed or captured unless in a person's self-defence, or because of damage being caused. Capturing and shooting were to be permitted by licence only, to be granted by District Magistrates. Local Governments were empowered from time to time to make rules, consistent with the above Act, to regulate the conditions under which licences for capture and shooting were to be issued, and so forth. 


\section{Cultivator versus Wild Elephant}

Apart from the fact that there is usually a ready market for elephants, there is a further reason why they must be captured-or at any rate controlled by shooting. With the spread of civilization and growth of population, the area under cultivation for the production of food has rapidly extended during recent decades. Consequently the former feedinggrounds of wild elephants have diminished, and these animals encroach on rice fields and do considerable damage to crops. It was recently claimed by a speaker in the Assam Assembly that 100,000 acres of land which could have been cultivated were not taken advantage of because of the presence of wild elephants. And that this would be the equivalent of 2,400,000 maunds of paddy, or $1 \frac{1}{4}$ per cent of India's food deficit.

"Exterminate wild elephants" then becomes the cry of the cultivators and some politicians, while against them are ranged the professional elephant-catchers and the buyers and users of trained elephants. The public and the government have to develop a balanced view of the whole matter, and the answer would appear to be a strict control, as is already practised in Assam and other elephant-holding countries.

The valuable stock of wild elephants must not be allowed to shrink below a specified danger-level; for it seems to be a law of Nature that should any wild animal or bird become increasingly rare, it eventually becomes extinct. It would be a major tragedy if such a noble and valuable creature as the elephant were allowed to suffer this fate. On the other hand, although huge in size and slow in movement, our present-day elephant shows no signs of going the way of the eleven different species of elephants and mastodons which have long been extinct. Rather it strongly holds its own, and if unchecked tends to multiply alarmingly.

\section{System of Control in Assam}

The policy in Assam has been to issue control licences to approved and experienced sportsmen, for the shooting of rogues, and in addition to this the right to conduct elephant-catching operations is leased out in those particular areas where elephants are known to be on the increase or causing serious damage to crops. Thus a careful control is kept on the population of these animals throughout the whole province, a specified number being allowed to be captured or destroyed each year.

In this connection an interesting survey of wild elephants was carried out in Burma before the war. A careful census made 
in 1935 put that country's elephant population at about 10,000 head. Reckoning on 6,000 of these being females, and half of these being of breeding-age, and at the rate of one calf in four years, the average annual birth-rate would be 750. From this subtract 125 natural deaths each year, which leaves the average annual increase of 10,000 animals at 625 . Therefore the latter number of elephants should be safely captured or destroyed each year in Burma, without increasing or diminishing the stock.

Assam has adopted this same formula, but the great difficulty is to assess correctly the elephant population of the province. In 1942 it was put at 5,000, whereas now the Forest Department consider it may be as low as 2,000 . If this latter figure is correct, then only 125 wild elephants can be captured or killed annually in Assam without causing a serious decline in the stock of elephants. This is of special importance, as Assam is the chief source of supply of elephants to the northern and western provinces of India.

During 1946-7, 377 wild elephants were captured or destroyed in Assam, 366 in 1947-8, and 393 in 1948-9. The number of wild elephants still in existence does not seem to have diminished, so it must well exceed 2,000 .

With the present chaotic conditions in Burma, great concern is felt by all for the safety of its national assets, of which elephants are one, and without which the teak industry would suffer considerably. In south India, so far as I understand, the elephant population is more or less static, any natural increase having been offset by captures and prescribed rogues being shot. In Mysore State during the last two seasons 140 elephants are reported to have been captured in two kheddas.

It would appear, then, to be our duty to avoid exposing the cultivator too much to the danger of losing his hard-earned crops, and at the same time to protect from rarity or extinction the magnificent wild elephants of India.

\section{The Humanizing of Catching Operations}

In the olden days there was a great deal of brutality in the capture and initial training of wild elephants. The death-rate from strangulation, septicæmia, and starvation was very highoften as much as 70 per cent. Cruel methods were employed. For instance, elephant catchers on specially selected koonkies (trained elephants used for catching operations) would seek out and run down a wild one in the jungle. Each mahout had a man with him who "assists to drive the koonkie by perpetually striking it on a sore kept raw for that purpose near 


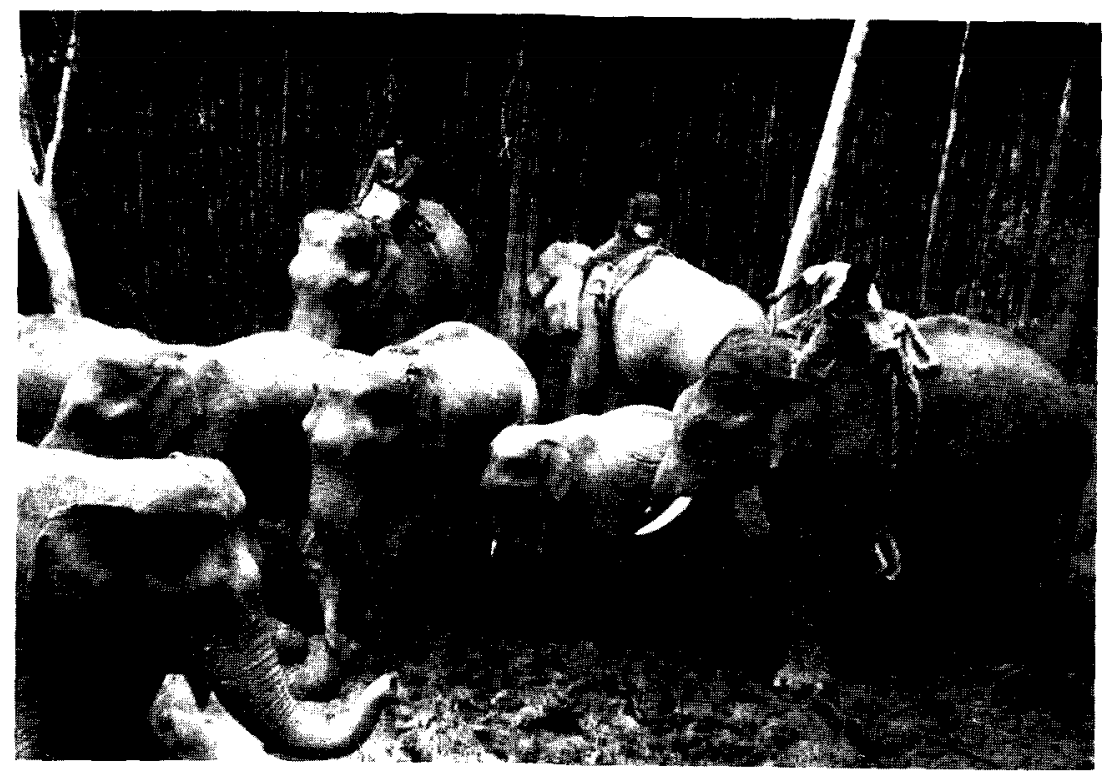

Thetoyraph by E. P'. Ciee. EIJPHANT CATCHING IN ASSAM. THE STOCKADE METHOD.

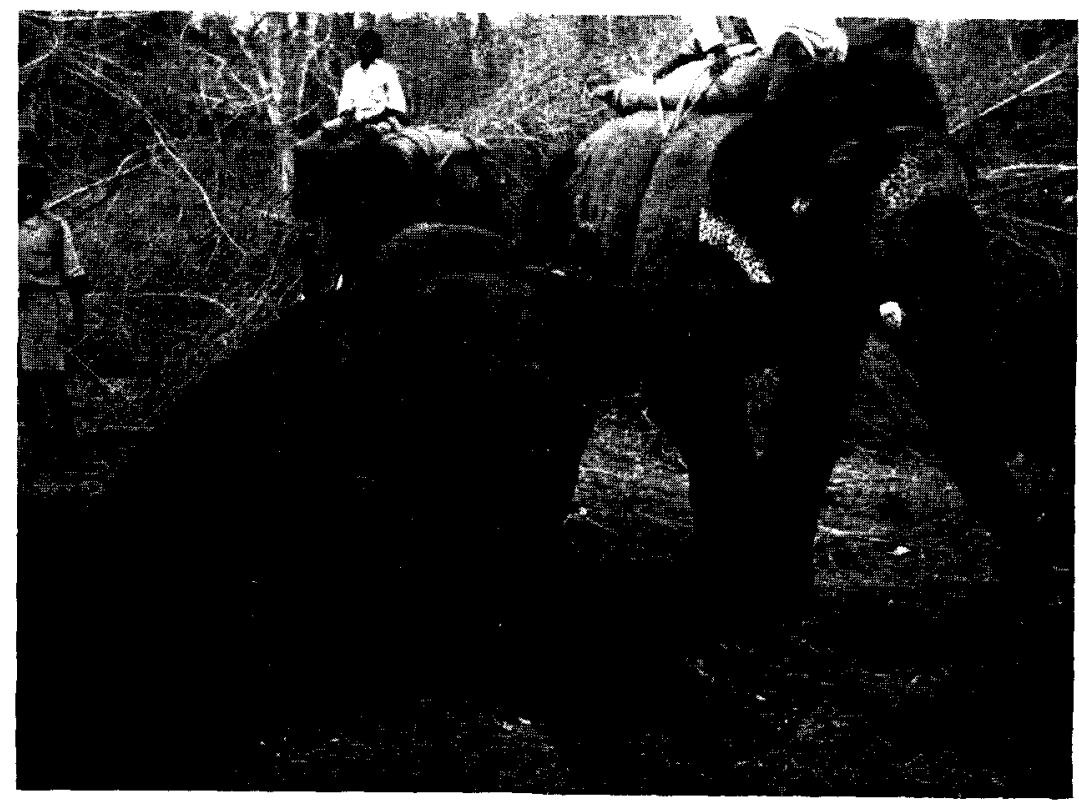

Thotograph by Hajor C.C. Wilson.

BLEPHANT CATCHING IN SOLTHERN INDIA. THE PIT METHOD. 
the root of the tail". The wild elephant was thus chased for several miles through the jungle till it slowed up or fell through fright and exhaustion, when it was roped and led back to the depot.

Lieut.-Col. Pollok, writing of this in his book published in 1879 , also says ". . . it is now forbidden in our parts of India." Elephants were also caught " . . . in pitfalls, now forbidden in our territories, but still practised in independent states". The method of catching by digging pits can be cruel, but on the other hand by improved methods it can be made entirely humane; and elephants are still successfully caught in this way nowadays by the Madras Forest Department. In Assam, too, rhinoceroses have in recent years been humanely caught by the pit method, and the animals are removed immediately after they are trapped - even should it happen to be during the night.

The pit method of capturing wild elephants was abandoned in Ceylon, I believe, several hundred years ago. But at the present day in that country it appears that snares are laid, often indiscriminately, resulting sometimes in prolonged suffering and even death to the unfortunate elephant.

\section{The Stockade Method}

The best known and most successful, though most expensive way of catching elephants is the khedda, or stockade method. This has been practised all over Asian countries holding elephants from time immemorial. Here, too, the captured animals can be subjected to considerable cruelty. For example, Lieut.-Col. Pollok writes of elephants caught in a stockade: " . . for several days they are carefully watched before any attempt is made to remove them. When their spirit has been sufficiently broken by hunger and thirst, a party of picked koonkies . ..." $\mathrm{He}$ further states that many died of "strangulation and mortification ".

That was in the India of seventy years ago. All is quite different now, and the province of Assam in particular may justly claim to lead the world in its efficient control of elephant catching. To the late Mr. A. J. W. Milroy, Assam's greatest Conservator of Forests, is due the highest praise for humanizing by legislation the brutal elephant catching operations of his day. Due to him, these became humane and carefully organized procedure, in which a minimum amount of suffering is experienced by the elephants and their mortality rate decreased from about 40 per cent to no more than 3 per cent. In these 
"Elephant Hunting Rules" of 1930, among many other regulations are to be found the one enjoining that fodder and water in wooden troughs be provided for wild elephants not removed from the stockade within twenty-four hours after capture. And all elephants not removed within ninety-six hours of capture must be released unconditionally and without injury. Also all pregnant females and those with sucking calves under one year old as well as old and sickly animals, must be sct frec immediately.

The District Magistrate, moreover, is empowered under these rules to release, destroy, or put under medical treatment at the catcher's expense any captured elephants suffering from lack of fodder or water or by reason of mutilation, starvation, or treatment. A host of other similar rules enforce the best possible treatment of captured elephants, and any defaulter is liable to be black-listed or heavily punished.

\section{Mela Shikar}

Another form of elephant catching, usually done in Assam along with the stockade, is mela shikar. A few specially selected koonkies, ridden by the most experienced mahouts, roam through the jungle. When they come across a suitable half or three-quarter grown wild elephant, they approach right up to it and effect the noosing of it. Koonkies in mela shikar generally keep within call of each other, so as to be able to render assistance to each other if necessary.

This method is the simplest and most inexpensive way of catching elephants, but calls for a considerable amount of skill and courage. No gun is allowed to be carried in this form of elephant hunting; while four guns per stockade are allowed for khedda operations-chiefly for creating a noise when the herd is about to be driven into the enclosure. The method employed in the Belgian Congo in Africa is in some ways similar to mela shikar-except that the hunting is done on foot or on horseback. A herd of elephants is scared away by the firing of shots, and a youngster in the rear is caught by the tail and its legs roped one by one.

\section{Some Elephant Myths}

Elephants are often supposed not to breed in captivity. But given favourable conditions, such as being allowed to graze in adjacent jungle, tame elephants frequently do produce calves. Elephant owners, however, do not as a rule give facilities to their animals to breed, as this would result in loss of work 
and, therefore, of income. And the offspring would be an expense and a liability till it reached the age of about fourteen, when it could start to earn its living. A baby elephant was born in the London Zoo in 1902, and another in Copenhagen in 1907, and therc are probably many more such cases.

Another popular belief is that an elephant's trunk is used as a powerful weapon of attack and as a useful limb for work. Actually, an elephant's trunk is an extremely delicate and sensitive organ of smell and touch; and when an elephant charges, its trunk is usually coiled up for safety's sake. It will break branches and lift objects with its trunk, as in collecting its fodder. But when hauling timber it takes the rope between its teeth or else works in harness.

Another belief, popular with fiction writers and others, is that elephants resort to some common burial place to die, and that masses of ivory await the finder. But this is not borne out by actual field observation; and innumerable instances have been reported of elephants dying natural deaths-just anywhere. In the type of country which they frequent, a carcase will soon vanish in a mass of quick growing jungle. A case is recorded of a fully-grown dead cow elephant completely disappearing in the space of two months, except for the skull and thigh bones. The grass and vegetation, killed at first by a superabundance of putrefying flesh and blood, eventually grew in much greater profusion than before, completely obliterating from view all traces of the skeleton.

To the foregoing myth is probably related the one about the elephant's longevity. Here again fabulous stories should be discounted. Those really conversant with elephants agree that three score years and ten is about the average span of their life, the ones heavily worked in captivity having a shorter term of life than their brothers in the jungle. In fact their growth and age coincide fairly accurately with those of man.

Pregnancy, lasting from eighteen to twenty-two months, is longer for males and shorter for females. A baby elephant suckles for at least a year and is generally found following its mother up to the age of about five. At about sixteen it becomes a parent and a female may produce about once every three or four years. At about thirty to forty it is fully mature and in its prime. At forty to fifty it is past its best.

\section{A Baby Elephant is Found}

Recently a suckling calf of about four months old was found wandering by itself close to the elephant-catching depot near 
Golaghat, where the Doyang River meanders through thick jungle country midway between the Naga Hills and the huge Brahmaputra. It had somehow become separated from its mother. News was sent to the manager of the elephant-catching operations, and a koonkie and some men were dispatched to secure it and bring it in. Had it been left alone, it would have fallen an easy prey to the first roaming tiger or leopard. A $3 \mathrm{ft} .2$ in. baby female, she was put on the bottle and soon became quite tame with the Assamese mahouts and trainers in the camp, and was called Sabitri.

The Calcutta and London Zoos were informed and immediately the latter arranged for her travel by air from Assam to England. After a flight which made elephant history, she was rechristened Dumbo on arrival at London; and it is hoped that this real flying elephant will thrive in her new home and never miss the luscious green jungles of Assam, the place of her birth.

\section{THE APES OF GIBRALTAR}

\section{By Sir Claud Russelu, K.C.M.G.}

It is, I think, common knowledge that in the course of the war the defences of Gibraltar were strengthened, the garrison reinforced, and the civilian population largely evacuated. But there was another notable measure taken which, so far as I know, has escaped publicity. It is not easy to come by information on the affairs of Gibraltar, but the local belief is that during a bricf official visit to the Rock, Mr. Churchill became aware that the famous Apes had so decreased in numbers as to make their continued existence precarious. Conscious, no doubt, of our Society's good purpose, and aware, perhaps, of the age-long belief that if ever the Apes should come to an end a like fate would befall our possession of Gibraltar, the Prime Minister gave an urgent order that the Apes should be increased by such a number as would ensure their preservation. This was done by an importation of monkeys of the same species (Macaca sylvana) from Barbary, across the Straits, and these are now, to all appearance, well established in their new home. Their location is about half-way up the Rock, and accessible by road. A soldier of the garrison has charge of 